GRASAS Y ACEITES 68 (3)

July-September 2017, e209

ISSN-L: 0017-3495

doi: http://dx.doi.org/10.3989/gya.1276162

\title{
Fatty acids profile and nutritional composition of two tropical diatoms from the Costa Rican Pacific Coast
}

\author{
K. Rodríguez-Núñez ${ }^{\mathrm{a}, \mathrm{b}, \varpi}$ and P. Toledo-Agüero ${ }^{\mathrm{c}}$ \\ ${ }^{\text {a }}$ Programa de Magíster en Acuicultura, Facultad de Ciencias del Mar, Universidad Católica del Norte, Larrondo 1281, \\ Coquimbo, Chile.
${ }^{\mathrm{b}}$ Estación de Biología Marina, Escuela de Ciencias Biológicas, Universidad Nacional de Costa Rica, Avenida 1 Calle 1, \\ Heredia 86-3000, Costa Rica. \\ ' Departamento de Acuicultura, Facultad de Ciencias del Mar, Universidad Católica del Norte, Larrondo 1281, Coquimbo, Chile. \\ ${ }^{\otimes}$ Corresponding Authors: karen.rodriguez01@ucn.cl; ptoledo@ucn.cl
}

Submitted: 20 December 2016; Accepted: 07 June 2017

\begin{abstract}
SUMMARY: Microalgae represent an important nutritional source for diverse organisms, therefore, their nutritional value, and more specifically, total lipid and fatty acid contents, must be considered. This study evaluated the nutritional contents and potential growth under controlled conditions of Nitzschia sp. and Chaetoceros sp. Tropical microalgae, isolated from the Gulf of Nicoya, Costa Rica. In both strains, the nutritional composition and the fatty acid profile were evaluated in exponential and stationary phases. With regards to fatty acids, Nitzschia sp. had more Eicosapentaenoic Acid (EPA) in both the exponential (32.80\%) and stationary $(27.20 \%)$ phases. The results in growth rate, production and biochemical composition indicated two tropical microalgae strains suitable for cultivation under controlled conditions. The studies of the phytoplankton in this geographical area is highly relevant because of its importance in the primary production of nutrients and the importance of finding sources of fatty acids such as the EPA.
\end{abstract}

KEYWORDS: Bacillariophyceae; Chemical composition; Costa Rica; Fatty acids; Microalgae cultures

RESUMEN: Perfil de ácidos grasos y composición nutricional de diatomeas tropicales aisladas de la costa del Pacífico de Costa Rica. Las microalgas representan una fuente alimenticia importante para diversos organismos, por lo que su valor nutricional debe ser considerado, especialmente su contenido de lípidos totales y el perfil de ácidos grasos. Este estudio tuvo como objetivo evaluar el crecimiento y determinar la composición bioquímica de dos cepas de microalgas tropicales aisladas de la costa del Pacífico Central de Costa Rica, Nitzschia sp. y Chaetoceros sp. En ambas se evaluó la composición nutricional y perfil de ácidos grasos en fase exponencial y estacionaria. Nitzschia sp. tuvo mayor cantidad de ácido eicosapentanoico (EPA) en ambas fases $(32.80 \%$ y $27.20 \%$, respectivamente). Los resultados en tasa de crecimiento, producción y composición bioquímica, presentan dos cepas de microalgas tropicales aptas para su cultivo en condiciones controladas. Estudiar el fitoplancton de esta zona es muy relevante debido a su importancia en la producción primaria y en la búsqueda de fuentes de ácidos grasos como el EPA.

PALABRAS CLAVE: Ácidos grasos; Bacillariophyceae; Composición química; Costa Rica; Cultivos microalgales

ORCID ID: Rodríguez-Núñez K http://orcid.org/0000-0001-7644-4482, Toledo-Agüero P http://orcid. org/0000-0003-3844-1824

Citation/Cómo citar este artículo: Rodríguez-Núñez K, Toledo-Agüero P. 2017. Fatty acid profile and nutritional composition of two tropical diatoms from the Costa Rican Pacific Coast. Grasas Aceites 68 (3), e209. http://dx.doi. org/10.3989/gya.1276162

Copyright: (C) 2017 CSIC. This is an open-access article distributed under the terms of the Creative Commons Attribution (CC-by) Spain 3.0 License. 


\section{INTRODUCTION}

Microalgae are an important source of nutrients and food for diverse organisms (Conceição et al., 2010). This importance arises due to a number of key characteristics of microalgae, including cell size, ease of production, protein and lipid contents and quality (Renaud et al., 1994; Huerlimann et al., 2010). Under appropriate conditions, these microorganisms can duplicate in biomass during the logarithmic growth phase in less than $24 \mathrm{~h}$, although this rate varies among species (Abou-Shanab et al., 2011). After the establishment of an algal culture, their nutritional value must be determined; particularly, the protein and lipid contents are the most important organic components to consider (Huerlimann et al., 2010).

The biochemical composition of microalgae varies among species, although culture conditions are generally similar. However, each microalgae culture differentially responds to nutrient availability and proportions (Prieto et al., 2005; Huerlimann et al., 2010). Nutrient contents also fluctuate based on the developmental phase, where, for example, a typical culture under standard conditions contains 30-40\% protein, 10-20\% lipids, and 5-15\% carbohydrates at the end of the logarithmic phase. In the stationary phase, when nitrates are limited, storage products such as carbohydrates and lipids can double (Roncarati et al., 2004).

When selecting a microalgae species as a source of nutrients, the lipid profile should be analyzed. It is also necessary to determine the fatty acid (FA) profile (Renaud, 1994; Huerlimann et al., 2010; Tocher, 2015). Since in the last years special interest in the nutritional balance contributed by the FA has arisen (Tocher, 2015) it is important to know the lipid profile. The FA composition is species-specific and is a relevant criterion in nutrition (Roncarati et al., 2004). Particularly, it is important for diets containing marine organisms to contain highly unsaturated fatty acids (HUFAs), especially EPA (C20:5n3) and docosahexaenoic acid (DHA, C22:6n3) (Delaporte et al., 2005).

Currently, microalgae constitute a primary source of HUFAs (Hinzpeter et al., 2006), with EPA being one of the most studied due to its wellknown effects on the cardiovascular system of organisms, where, in humans, EPA effectively acts against cancer, coronary cardiomyopathology, schizophrenia, and rheumatoid arthritis (Ward and Singh, 2005; Hinzpeter et al., 2006; Conceição et al., 2010; Tocher, 2015). EPA may decrease muscle waste, can reduce inflammation and has the potential to modulate nutritional status/body composition. Marine fatty acids such as EPA and DHA inhibit leukotriene-mediated inflammation which leads to atherosclerosis in subpopulations with increased risk (Simopoulos, 2006).
The marine microalgae culture, like diatoms, could offer the ideal long-term, sustainable solution for EPA demand (Tocher, 2015). A variety of strategies has been devised to enhance the production of EPA and many authors have investigated processes for the increased production of EPA by diatom algae. The intensive production of FA would require algae to simultaneously demonstrate high growth and high proportions of EPA and DHA. These can be almost exclusive traits as lipid deposition is often associated with conditions when growth is limited (e.g. Nitrogen limitation, in stationary phase) (Tocher, 2015). Nitzschia alba and N. laevis have been studied because of the large EPA levels produced by these microorganisms (Ben-Amotz et al., 1985; Ward and Singh, 2005).

Considering the importance of microalgae nutritional contents, the aim of the present study was to characterize the growth and nutritional composition of two Bacillariophyceae diatoms obtained from the Pacific coast of Costa Rica. These diatoms were Nitzschia sp. and Chaetoceros sp., which are often considered candidates for obtaining essential marine HUFAs.

\section{MATERIALS AND METHODS}

\subsection{Algae cultures and growth rates}

Two marine microalgae were selected from the strain database managed by the Center of Marine Biology (EBM) of the Universidad Nacional de Costa Rica. These strains were originally isolated off the Gulf of Nicoya, Costa Rica, and classified as belonging to the Nitzschia sp. and Chaetoceros sp. (Rodríguez-Núñez et al., 2016).

For culture assays, the f/ 2 culture medium was used (Guillard, 1975). This medium was prepared with seawater filtered at $1 \mu \mathrm{m}$ and sterilized with UV light (Model QL-240, eight lamps). For both strains, three culture volumes $(150,1500$, and 8000 $\mathrm{mL}$ ) were assessed in 250 and $2000 \mathrm{~mL}$ flasks and $10000 \mathrm{~mL}$ glass bottles, respectively. Each volume was cultured in triplicate. Luminous intensities were $14-16 \mu \mathrm{mol} \cdot \mathrm{m}^{-2} \mathrm{~s}^{-1}(150 \mathrm{~mL}), 30-35 \mu \mathrm{mol} \cdot \mathrm{m}^{-2} \cdot \mathrm{s}^{-1}$ $(1500 \mathrm{~mL})$, and $50-55 \mu \mathrm{mol} \cdot \mathrm{m}^{-2} \cdot \mathrm{s}^{-1}(8000 \mathrm{~mL})$, while the remaining variables were constant for all assays, including salinity (33 psu), $\mathrm{pH}(8.3 \pm 0.2)$, temperature $\left(22 \pm 1^{\circ} \mathrm{C}\right)$, and photoperiod $(12: 12 \mathrm{~h}$ light:dark).

The doubling time was determined by the three repetitions used for each volume, with $1 \mathrm{~mL}$ samples taken every $12 \mathrm{~h}$ and fixed with $1 \%$ Lugol's iodine solution. A haemocytometer was used to perform at least four cell counts per sample. Once the doubling time for the $150 \mathrm{~mL}$ culture was obtained, the end-point of logarithmic growth was determined to inoculate the $1500 \mathrm{~mL}$ culture and, likewise, the $8000 \mathrm{~mL}$ culture. 


\subsection{Characterization of cultures and statistics}

From the microalgae cultured, growth rate $(\mathrm{K})$, culture productivity $(\mathrm{P})$, and the accumulated media (in terms of cells per $\mathrm{mL}^{-1}$ ) were determined. For all volumes used in this study $\mathrm{K}$ and $\mathrm{P}$ (in logarithmic phase) were used to characterize the culture using the following formulas: $\mathrm{K}=\left(\ln \mathrm{C}_{\mathrm{f}}-\ln \mathrm{C}_{\mathrm{i}}\right) \cdot\left(\mathrm{t}_{\mathrm{r}}-\mathrm{t}_{\mathrm{i}}\right)^{-1}$ and $P=\left(C_{f}-C_{i}\right) \cdot\left(t_{f}-t_{i}\right)^{-1}$, where $C_{i}$ : initial concentration, $\mathrm{C}_{\mathrm{f}}$ : final concentration of the exponential phase, and $t_{\mathrm{f}}-\mathrm{t}_{\mathrm{i}}$ : duration of the exponential phase in days (Levasseur et al., 1993).

Normal data distribution was confirmed using the Kolmogorov-Smirnov and Lilliefors Normality Tests, following the methodology proposed by Bhujel (2009). To determine the endpoint for each culture phase (growth curve) the $P$ values were used. A one-way analysis of variance was applied, using time as a variable. For the statistical analyses, the STATISTICA v7.0.61.0 software (Statsoft, Inc.) and Excel 2010 (Microsoft Corporation) were used.

\subsection{Determination of chemical composition}

Both strains were cultured in $10000 \mathrm{~mL}$ bottles filled with $8000 \mathrm{~mL}$ of $\mathrm{f} / 2$ culture medium. The nutritional composition was evaluated during two phases of the growth curve, with 12 repetitions during the logarithmic phase and 8 during the stationary phase. It was necessary to harvest 12 and 8 replicas for strain for biochemical analyzes of logarithmic and stationary phase. The harvesting points were previously defined in assays determining doubling time. Three samples of $1 \mathrm{~mL}$ were taken every $24 \mathrm{~h}$ and when harvesting the entire biomass. For observing the system conditions, culture samples were taken.

The harvested biomass was centrifuged for 10 min at $4000 \mathrm{rpm}$ (Model U-320R, Boeco, Germany). The obtained sample was maintained at $-20{ }^{\circ} \mathrm{C}$. The total harvest was mixed and lyophilized (Ilshin FD-8505, Korea); except $5 \mathrm{~g}$ of biomass, which were used to determine moisture (\%). To obtain the biomass of each strain the moisture value was used. The following lyophilized biomass characteristics were determined in triplicate: moisture, ash, crude protein, total lipids and fiber contents; and fatty acid profile.

Moisture was determined by drying the samples in an Oven (Model FD 110, Binder, USA) at $95^{\circ} \mathrm{C}$ until reaching a constant weight (Method 930.04; AOAC, 2000). Ash content was determined by calcining the samples at $500{ }^{\circ} \mathrm{C}$ for $8 \mathrm{~h}$ in a muffle oven (Model Furnace 6000, Barnstead/Thermolyne, United Kingdom) (Method 930.05; AOAC, 2000). To determine crude protein content, Kjeldahl Nitrogen determinations were performed (DK 20, Velp Scientifica, Italy) (Method 978.04/955.04;
AOAC, 2000). Total lipids were assessed using the Soxhlet method (solvents: chloroform/metanol, 2:1, v/v; Ser 148, Velp Scientifica, Italy) (Method 920.39, AOAC, 2000). In turn, fiber quantity was assessed using the modified Weende Method (Fiwe, Velp Scientifica, Italy) (modified according to Method 962.09, AOAC, 2000,) on a supernatant sample taken from the previously performed total lipid assessments.

To establish the Fatty Acid Methyl Ester (FAME) profile (Supelco TM 37 Component FAME Mix, Sigma-Aldrich, $10 \mathrm{mg} \cdot \mathrm{mL}^{-1}$ in methylene chloride), which included saturated Fatty Acids (SFAs), Monounsaturated Fatty Acids (MUFAs), and Polyunsaturated Fatty Acids (PUFAs), the lipids were extracted when cold using the modified Folch Method (Folch et al., 1957, Pierce Chemical Company Manual), fatty acid derivatization, and chromatographic analysis (Gas Chromatograph with Flame Ionization Detector GC-FID, CLARUS 600, Perkin Elmer). The conditions of chromatography were as follows: column, $30 \mathrm{~m} \mathrm{x} 0.32 \mathrm{~mm}$ x $0.25 \mu \mathrm{m}$ (Omega Wax320); injector, $250{ }^{\circ} \mathrm{C}$; FID detector, $260{ }^{\circ} \mathrm{C}$; Carrier-gas, $\mathrm{He} 1 \mathrm{~mL} \cdot \mathrm{min}^{-1}$ (22 $\mathrm{cm} \cdot \mathrm{s}^{-1}$, approximately); injection volume, $1 \mu \mathrm{L}$; a split ratio, 100:1. The oven was held at $140{ }^{\circ} \mathrm{C}$ for 5 min before being increased to $240{ }^{\circ} \mathrm{C}$ at a rate of $2{ }^{\circ} \mathrm{C} \cdot \mathrm{min}^{-1}$ over $60 \mathrm{~min}$. All analyses were performed at the Algal Research and Tech Development Center of the Universidad Católica del Norte (CIDTA). FAMEs were analyzed in duplicate.

The logarithmic and stationary phases of both strains were compared. The data obtained for total lipid, crude protein, biomass moisture, EPA and DHA levels were compared using the Student's $t$-test for the two samples (Bhujel, 2009).

\section{RESULTS}

\subsection{Microalgae growth rates and characterizations}

The culture acclimation time was 1-2.5 $\mathrm{d}$ for all volumes of Nitzschia sp. used (Figure 1) and $12 \mathrm{~h}$ and $2 \mathrm{~d}$ for all volumes of Chaetoceros sp. used (Figure 2). The end of the exponential phase in $8000 \mathrm{~mL}$ volume was $3.5 \mathrm{~d}$ for both microalgae species. The highest value of $\mathrm{P}$ was obtained in $150 \mathrm{~mL}$ volumes for both species (Table 1).

\subsection{Microalgae nutritional compositions}

Nitzschia sp. presented approximately 10\% more biomass than Chaetoceros sp. (Table 2). Significant differences in moisture were found between the logarithmic and stationary phases for both Nitzschia sp. $(P=0.009)$ and Chaetoceros sp. $(P=0.004)$. Likewise, significant differences were found when comparing the logarithmic $(P<0.001)$ and stationary $(P<0.001)$ phases between strains. 


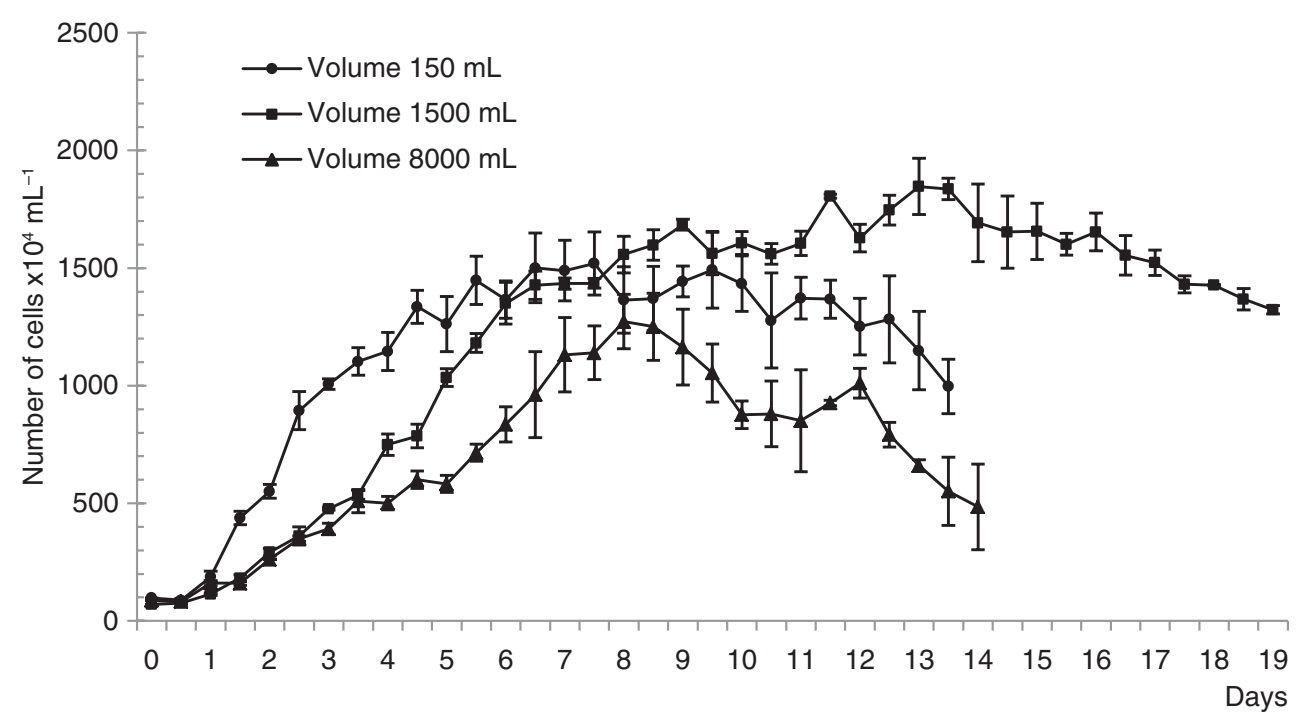

FIGURE 1. Nitzschia sp. growth kinetics when cultured with three volumes of the f/2 medium.

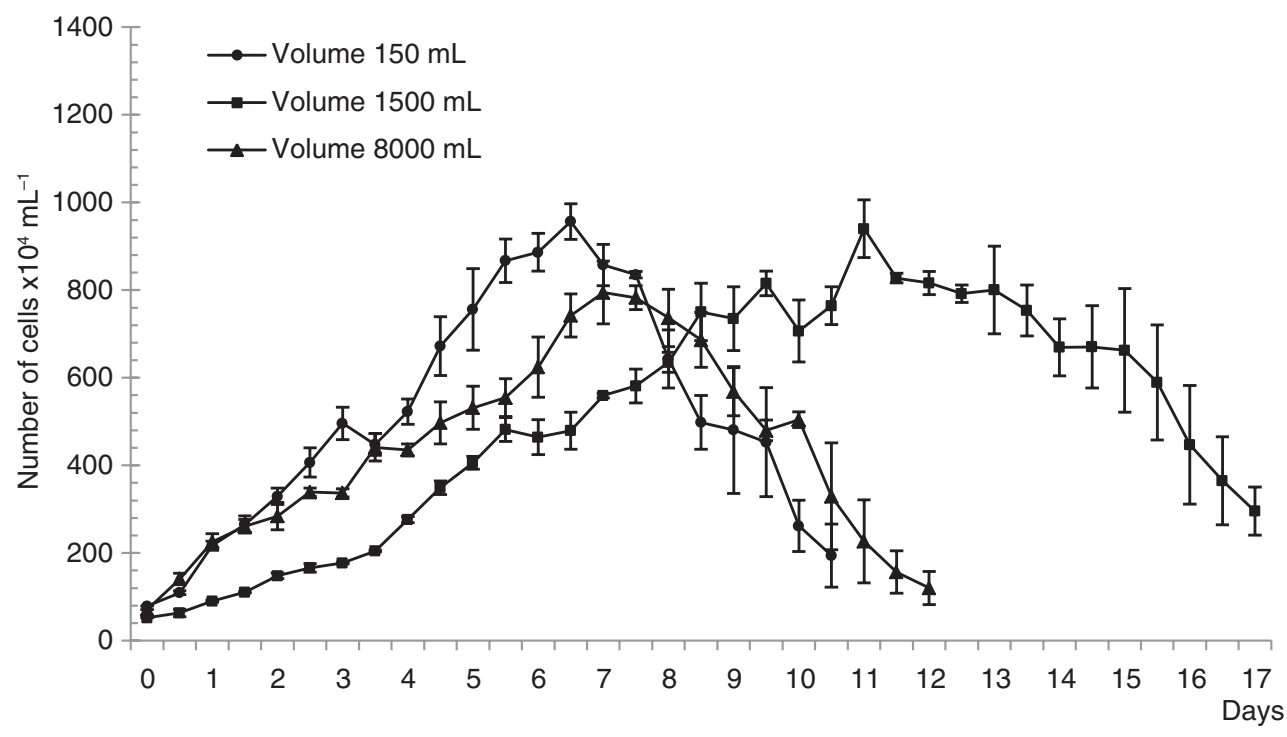

FIGURE 2. Chaetoceros sp. growth kinetics when cultured with three volumes of the f/2 medium.

The main biochemical component of Nitzschia sp. was protein in the logarithmic and stationary phases. Chaetoceros sp. evidenced elevated protein levels in the logarithmic phase and the main biochemical component of the stationary phase was ash content (Table 2). For both strains, ash contents were higher in the logarithmic phase. Significant differences were also recorded between the logarithmic and stationary phases $(P<0.001)$ of Chaetoceros $\mathrm{sp}$. For both strains, fiber values were not detected in the two culture phases.
For both strains, crude protein contents were higher than total lipid contents in the logarithmic phase. Comparing the logarithmic and stationary phases, significant differences were found for Nitzschia sp. $(P<0.001)$ and Chaetoceros sp. $(P<$ $0.001)$. Significant differences were also recorded between strains when comparing the logarithmic $(P<0.001)$ and stationary phases $(P<0.001)$. Regarding total lipid contents, the logarithmic and stationary phase comparisons showed significant differences for Nitzschia sp. $(P<0.001)$ and 
Fatty acids profile and nutritional composition of two tropical diatoms from the Costa Rican Pacific Coast $\bullet 5$

TABLE 1. Nitzschia sp. and Chaetoceros sp. density, growth rate, and productivity in three culture volumes

\begin{tabular}{lcccccc}
\hline Strain & V & F & D & K & P & $P$ \\
\hline Nitzschia sp. & 150 & 4.5 & $13353611 \pm 703520$ & 0.58 & $2.75 \times 10^{6}$ & $P>0.1$ \\
& 1500 & 5 & $10344444 \pm 370928$ & 0.54 & $1.93 \times 10^{6}$ & $P>0.1$ \\
Chaetoceros sp. & 8000 & 3.5 & $5097777 \pm 493305$ & 0.51 & $1.21 \times 10^{6}$ & $P>0.1$ \\
& 150 & 4.5 & $6386666 \pm 670575$ & 0.48 & $1.31 \times 10^{6}$ & $P>0.1$ \\
& 1500 & 5 & $4061944 \pm 145640$ & 0.41 & $7.08 \times 10^{5}$ & $P=0.0016$ \\
& 8000 & 3.5 & $4412222 \pm 309663$ & 0.52 & $1.06 \times 10^{6}$ & $P>0.1$ \\
\hline
\end{tabular}

V: culture volume $(\mathrm{mL}), \mathrm{F}$ : end of exponential phase (days), D: final density of exponential phase (cells $\mathrm{mL}^{-1}$ ) with standard deviation, $\mathrm{K}$ : rate growth, $\mathrm{P}$ : productivity (cells $\mathrm{mL}^{-1}$ ), $P$ : significance between $\mathrm{P}$ values.

TABle 2. Chemical composition and moisture content and of Nitzschia sp. and Chaetoceros sp., biochemical compounds expressed as percentages of dry weight, during the logarithmic and stationary phases (mean \pm standard deviation, $n=3$ )

\begin{tabular}{|c|c|c|c|c|c|c|c|c|}
\hline \multirow[b]{2}{*}{ Strain } & \multirow[b]{2}{*}{ Phase } & \multicolumn{2}{|c|}{$\%$ Moisture } & \multicolumn{4}{|c|}{$\%$ Biochemical compound } & \multirow[b]{2}{*}{ Fiber } \\
\hline & & Biomass** & $\begin{array}{c}\text { Lyophilized } \\
\text { biomass }\end{array}$ & $\begin{array}{l}\text { Total } \\
\text { lipids** }\end{array}$ & $\begin{array}{c}\text { Crude } \\
\text { protein** }\end{array}$ & Carbohydrates & $\operatorname{Ash}^{* *}$ & \\
\hline \multirow[t]{2}{*}{ Nitzschia sp. } & $\mathrm{L}$ & $81.13 \pm 0.04$ & $3.25 \pm 0.22$ & $18.36 \pm 0.28$ & $43.16 \pm 0.13$ & 18.88 & $19.60 \pm 0.06$ & nd \\
\hline & S & $80.31 \pm 0.38$ & $3.25 \pm 0.26$ & $28.31 \pm 0.32$ & $39.62 \pm 0.17$ & 13.80 & $18.27 \pm 0.09$ & nd \\
\hline \multirow[t]{2}{*}{ Chaetoceros sp. } & $\mathrm{L}$ & $88.60 \pm 0.03$ & $5.60 \pm 0.18$ & $19.28 \pm 0.20$ & $34.99 \pm 0.10$ & 10.78 & $34.95 \pm 0.12$ & nd \\
\hline & S & $90.14 \pm 0.36$ & $5.37 \pm 0.22$ & $23.78 \pm 0.17$ & $27.84 \pm 0.06$ & 17.19 & $31.20 \pm 0.11$ & nd \\
\hline
\end{tabular}

L: logarithmic phase, S: stationary phase, nd: undetected, ** Indicates significant differences between values of different phases between strain and the same phase between different strains using Student's $t$-test.

Chaetoceros sp. $(P<0.001)$. The strain comparisons evidenced differences between the logarithmic $(P=0.009)$ and the stationary phases $(P<0.001)$.

According to the obtained FA profiles, both strains contained C14:0, C16:0, C16:1, and EPA as the principle FAs (Table 3). In the logarithmic phase of Nitzschia sp., PUFAs represented the majority of the lipid contents, while SFAs were the least represented. In the stationary phase of Nitzschia sp., MUFAs were the principal component, followed by PUFAs. In contrast, both phases of Chaetoceros sp. evidenced SFAs as the principal component, with PUFAs as the least represented. Significant differences were obtained when comparing the EPA levels between the logarithmic and stationary phases of Nitzschia sp. $(P<0.001)$ and Chaetoceros sp. $(P=0.03)$. In turn, no significant differences were found between Chaetoceros sp.culture phases for DHA levels $(P=0.49)$.

\section{DISCUSSION}

Biomass and lipid productivity are critical parameters in selecting micro-algal species for scale-up production and nutritional applications. The lipid content refers to quantitative and qualitative lipid composition (Conceição et al., 2010; Huerlimann et al., 2010). Nitzschia sp. and Chaetoceros sp. evidenced short acclimation periods during scaling compared to other diatoms (Prieto et al., 2005). Due to this short period, the desired biomass can be reached in less time, in addition to reducing the risks of improper management. Furthermore, both microalgae species of this study were sufficiently supported in the culture conditions. In terms of productivity, this result is particularly important. Notably, the significantly different growth rates of the three evaluated volumes for both strains are data which could be used to optimize the resource volumes used for scaling. Therefore, the tolerance and rate of adaptation to environmental variation are factors that should be considered when selecting microalgae species for culturing and biomass production (Conceição et al., 2010).

Another characteristic used to evaluate microalgae potential is growth rate in terms of cell count or biomass. Ideally, microalgae should have a short lifecycle which is reproducible under controlled conditions (Araújo and García, 2005; Conceição et al., 2010). Comparisons were made between traditionally cultured microalgae and the currently evaluated strains. Knuckey et al. (2002, p. 260) evaluated Nitzschia cf paleacea and the Isochrysis aff. galbana clone T-ISO in a volume of $1600 \mathrm{~mL}$, and obtained growth rates of 0.55 and 0.56 , respectively. These values are very similar to those obtained for the Nitzschia sp. of this study. 
TABLE 3. Fatty acid composition, expressed as percentages of total fatty acids, of Nitzschia sp. and Chaetoceros sp. during the logarithmic and stationary phases (mean \pm standard deviation, $n=2$ )

\begin{tabular}{|c|c|c|c|c|}
\hline \multirow[b]{2}{*}{ Fatty acids } & \multicolumn{4}{|c|}{$\%$ FAMEs } \\
\hline & Nitzschia sp.(L) & Nitzschia sp.(S) & Chaetoceros sp. (L) & Chaetoceros sp. (S) \\
\hline \multicolumn{5}{|l|}{ SFAs } \\
\hline $\mathrm{C} 14: 0$ & $9.64 \pm 1.06$ & $8.68 \pm 0.04$ & $30.40 \pm 0.40$ & $31.70 \pm 0.40$ \\
\hline C15:0 & $0.53 \pm 0.20$ & $0.29 \pm 0.01$ & $0.75 \pm 0.09$ & $0.78 \pm 0.03$ \\
\hline C16:0 & $16.10 \pm 0.40$ & $15.30 \pm 0.09$ & $17.40 \pm 0.10$ & $17.30 \pm 0.10$ \\
\hline $\mathrm{C} 17: 0$ & $0.50 \pm 0.17$ & $0.04 \pm 0.01$ & nd & nd \\
\hline C18:0 & $0.79 \pm 0.24$ & $0.41 \pm 0.01$ & nd & nd \\
\hline C21:0 & nd & $0.16 \pm 0.01$ & nd & nd \\
\hline $\mathrm{C} 24: 0$ & nd & nd & $0.09 \pm 0.01$ & nd \\
\hline \multicolumn{5}{|l|}{ MUFAs } \\
\hline $\mathrm{C} 16: 1$ & $32.20 \pm 0.40$ & $39.70 \pm 0.20$ & $37.90 \pm 0.90$ & $38.20 \pm 0.20$ \\
\hline $\mathrm{C} 18: 1 n 9 \mathrm{c} / \mathrm{C} 18: 1 n 9 \mathrm{t}$ & $1.42 \pm 0.47$ & $1.99 \pm 0.02$ & nd & nd \\
\hline $\mathrm{C} 22: 1 n 9$ & nd & nd & $0.40 \pm 0.17$ & nd \\
\hline $\mathrm{C} 24: \ln 9$ & $0.72 \pm 0.20$ & $0.58 \pm 0.01$ & $0.13 \pm 0.03$ & nd \\
\hline \multicolumn{5}{|l|}{ PUFAs } \\
\hline $\mathrm{C} 18: 2 n 6 \mathrm{t}$ & $4.41 \pm 0.36$ & $3.71 \pm 0.01$ & nd & nd \\
\hline $\mathrm{C} 18: 2 n 6 \mathrm{c}$ & nd & nd & $2.00 \pm 0.14$ & $1.53 \pm 0.13$ \\
\hline $\mathrm{C} 18: 3 n 3$ & nd & $0.60 \pm 0.01$ & nd & nd \\
\hline $\mathrm{C} 18: 3 n 6$ & $0.89 \pm 0.45$ & $1.30 \pm 0.01$ & $1.08 \pm 0.16$ & $0.93 \pm 0.04$ \\
\hline $\mathrm{C} 20: 3 n 3$ & nd & nd & $2.75 \pm 0.25$ & $3.48 \pm 0.31$ \\
\hline $\mathrm{C} 20: 5 n 3$ & $32.80 \pm 2.20$ & $27.20 \pm 0.09$ & $6.44 \pm 0.06$ & $5.58 \pm 0.16$ \\
\hline $\mathrm{C} 22: 6 n 3$ & nd & nd & $0.53 \pm 0.22$ & $0.52 \pm 0.14$ \\
\hline$n-6 / n-3$ & 0.16 & 0.18 & 0.32 & 0.26 \\
\hline ¿SFAs & 27.60 & 24.90 & 48.80 & 49.80 \\
\hline ¿MUFAs & 34.30 & 42.30 & 38.40 & 38.20 \\
\hline ¿PUFAs & 38.10 & 32.80 & 12.80 & 12.00 \\
\hline
\end{tabular}

L: logarithmic phase, S: stationary phase, FAMEs: fatty acid methyl esters, SFAs: saturated fatty acids, MUFAs: monounsaturated fatty acids, PUFAs: polyunsaturated fatty acids, nd: undetected.

In contrast, the growth rates obtained by Renaud et al. (2002, p. 197) for Chaetoceros sp. $(\mathrm{K}=0.74)$ were superior to those obtained in this research. Knuckey et al. (2002, p. 260) also obtained higher values of $\mathrm{K}$ for other diatoms. Although the Chaetoceros sp. of this study presents a short culture acclimation time, its growth rate was inferior to other diatoms traditionally cultivated. That may be due the fact that this rate varies among species (Abou-Shanab et al., 2011).

The produced biomass should have appropriate nutritional contents. These contents can vary depending on strain and the phase in which the culture is harvested. In algal cultures, crude protein is the primary organic constituent during the logarithmic growth phase, with contents decreasing during the stationary phase as a consequence of decreased nitrogenous compounds in the medium. This situation occurs in batch culture, like the one used in this research. In continuous or semi-continuous culture this effect is partially counteracted by adding nutrients (Medina-Reyna and Cordero-Esquivel, 1998; Araújo and García, 2005; Tocher, 2015). This was observed in the present results for biochemical analyses. Renaud et al. (1994, p. 342) isolated tropical species from northern Australia, including marine diatoms that were cultivated under controlled conditions similar to those used in the current study. Comparisons between the protein contents of the Nitzschia frustulum in Nitzschia sp. of this study showed that it has higher protein levels than either of the previously assessed diatoms. Rivero-Rodríguez et al. (2007) assessed the biochemical compositions of five marine microalgae, including Chaetoceroscalcitrans. The crude protein content of Chaetoceros sp. in this study was $6 \%$ less than $C$. calcitrans.

Ash represents a large portion of the biochemical composition in diatoms, as occurs in the microalgae species of this study. This is mainly found in the Chaetoceros genus, due to the formation and constitution of the frustula. The strains showed a 
significant difference when comparing the percentage of ash in exponential and stationary phases. A higher value in the logarithmic stage may be due to a thicker frustula in the early stages of the culture (Medina-Reyna and Cordero-Esquivel, 1998; Pacheco-Vega and Sánchez-Saavedra, 2009).

Many microalgae species present changes in lipid content during the different phases of growth (Huerlimann et al., 2010; Su et al., 2013). Lipid content generally increases during the stationary phase as photosynthetic energy of the culture is diverted from cell division to lipid production, which is often triggered by limitations of nitrogen (Ben-Amotz et al., 1985; Huerlimann et al., 2010; Su et al., 2013). This behavior was found for the two presently studied strains, where Nitzschia sp. presented an increased total lipid content of $9.95 \%$ and Chaetoceros sp. Of $4.5 \%$. The Nitzschia genus is known for high lipid contents that can surpass even $40 \%$ (Ben-Amotz et al., 1985). In comparing the total lipid contents of the Nitzschia sp. of this study, with the values obtained by Renaud et al. (1994, p. 341), the levels of Nitzschia sp. were 2.41\% greater than previously reported. Likewise, the lipid contents of Chaetoceros sp.in the logarithmic phase were $7.9 \%$ higher than values reported by RiveroRodríguez et al. (2007), in addition to presenting values superior to those in other studies (Renaud et al., 2002; Delaporte et al., 2005; Pacheco-Vega and Sánchez-Saavedra, 2009).

As with lipids contents, the FA profile varies considerably between the different species or strainspecific (Hu et al., 2008; Huerlimann et al., 2010). However, in general terms for marine microalgae, PUFAs constitute most of the FA profile (BenAmotz et al., 1985; Hu et al., 2008), as evidenced by the Nitzschia sp. of this research. Moreover, the dominant FAs in both strains coincided with tendencies reported in the literature, specifically the C14:0, C16:0, C16:1, and EPA (Renaud et al., 1994; $\mathrm{Su}$ et al., 2013), values found in diatoms (Hu et al., 2008).

Roncarati et al. (2004, p. 406) assessed four algal strains and confirmed that the FA profiles presented differences in the same strain depending on the culturing phase. The results for Nitzschia $\mathrm{sp}$. and Chaetoceros sp. of this work coincided with prior findings by Su et al. (2013), in a study in which C16:1 FA content increased during logarithmic growth while EPA levels decreased. In the Nitzschia sp. of this study, C18:1 FA levels increased during the stationary stage, which could coincide with triacylglycerols acting as storage fats in algae, due to which, levels are generally low during the logarithmic phase (Ben-Amotz et al., 1985; Su et al., 2013).

Just as with diatoms previously studied, Nitzschia sp. and Chaetoceros sp. present high levels of EPA and low DHA levels (Delaporte et al., 2005; Hinzpeter et al., 2006; RiveroRodríguez et al., 2007; Conceição et al., 2010). EPA plays an important role in the prevention of arrhythmia, atherosclerosis, cardiovascular disease and cancer (Simopoulos, 2006). It is important to know that EPA and/or DHA are necessary for the animal and human population (Roncarati et al., 2004), and it is fundamental to study new sources of EPA and evaluate their potential, such as marine diatoms (Tocher, 2015), like the Nitzschia genus. Results of studies in Nitzschia reported high EPA levels (Conceição et al., 2010). When compared to values obtained in previous studies, the Nitzschia sp. of this research presented up to $16.8 \%$ more EPA (Renaud et al., 1994; Su et al., 2013). High EPA levels are very important and are associated with the production of PUFAs.

The lipid contents of Chaetoceros sp. of this study were similar or greater than other studies on the genus Chaetoceros (Renaud et al., 1994; Pacheco-Vega and Sánchez-Saavedra, 2009). The obtained EPA and DHA values were lower in both phases when compared to the values obtained for C. muelleri (13.44\% EPA and 6.86\% DHA, PachecoVega and Sánchez-Saavedra, 2009) and C. calcitrans reported in other investigations $(17.80 \% \mathrm{EPA}$ and $1.30 \%$ DHA, Delaporte et al., 2005). According to Ryckebosch et al., $(2012$, p. 130) for the genus Chaetoceros, EPA levels should be between 8 and $22 \%$, while DHA levels should be between 0.03 and $5 \%$. This may be due to the fact that lipid and FA levels are strain-specific, and these concentrations may present differences between the two species of the same genus (Roncarati et al., 2004; Huerlimann et al., 2010).

The performed assessments support the conclusion that microalgae behavior and biochemical composition are specific to each strain. Although the evaluated strains were cultured under identical conditions, significant differences were found in growth, productivity, biochemical composition, lipid levels and FA profile between strains and between developmental phases of the same strain.

\section{CONCLUSIONS}

In conclusion, the culture characteristics and nutritional compositions of the studied strains support further consideration of these diatoms for nutritional applications in the Central American region. Nitzschia sp. presented approximately 10\% more biomass than Chaetoceros sp., in addition to greater growth, higher productivity, and higher levels of protein, lipid, and EPA contents. Due to this, Nitzschia sp. is suggested as an option as a source of essential FA and EPA for animal and human nutrition. This study provides an initial foundation for further research, providing key information for the development of regional microalgae cultures. 


\section{ACKNOWLEDGEMENTS}

The authors acknowledge the aid provided by Mauricio López of the Nutritional Laboratory at the Universidad Católica del Norte (UCN) and the technical personnel of the Costal Center of the Faculty of Marine Sciences at UCN. The authors also acknowledge financial support provided by the Marine Biology Center of the Universidad Nacional de Costa Rica, the Consejo Nacional para Investigaciones Científicas y Tecnológicas de Costa Rica and the Nutritional Laboratory and the Master's Program in Aquaculture of the Faculty of Marine Sciences at UCN.

\section{REFERENCES}

Abou-Shanab R, Matter I, Kim S, Oh Y, Choid J, Jeon B. 2011. Characterization and identification of lipid-producing microalgae species isolated from a freshwater lake. Biomass Bioenerg. 35, 3079-3085. https://doi.org/10.1016/j. biombioe.2011.04.021

Araújo SC, García VMT. 2005. Growth and biochemical composition of the diatom Chaetoceros cf. wighamii brightwell under different temperature, salinity and carbon dioxide levels. I. Protein, carbohydrates and lipids. Aquaculture 246, 405-412. https://doi.org/10.1016/j. aquaculture. 2005.02.051

AOAC Association of Official Analytical Chemists. 2000. Official methods of analysis of AOAC International. W. Horwitz (ed) AOAC International, Gaitherburg, Maryland.

Ben-Amotz A, Tornabene TG, Thomas WH. 1985. Chemical profile of selected species of microalgae with emphasis on lipids. J. Phycol. 21, 72-81. https://doi. org/10.1111/j.0022-3646.1985.00072.x

Bhujel R. 2009. Statistics for Aquaculture. Wiley-Blackwell, Singapure.

Conceição L, Yúfera M, Makridis P, Morais S, Dinis MT. 2010. Live feeds for early stages of fish rearing. Aquac. Res. 41, 613-640. https://doi.org/10.1111/j.1365-2109.2009.02242.x

Delaporte M, Soudant P, Moal J, Kraffe E, Marty Y, Samain JF. 2005. Incorporation and modification of dietary fatty acids in gill polar lipids by two bivalve species Crassostrea gigas and Ruditapes philippinarum. Comp. Biochem. Phys. A 140, 460-470. http://dx.doi.org/10.1016/j.cbpb.2005.02.009

Ferrão-Filho AS, Fileto C, Lopes N, Arcifa MS. 2003. Effects of essential fatty acids and $\mathrm{N}$ and $\mathrm{P}$-limited algae on the growth rate of tropical cladocerans. Freshwater Biol. 48, 759-767.

Folch J, Less M, Sloane-Stanley GH. 1957. A simple method for the insolation and purification of total lipids from animal tissue. J Biol Chem 193, 265-275.

Gouda R, Kenchington E, Hatcher B, Vercaemer B. 2006. Effects of locally-isolated micro phytoplankton diets on growth and survival of sea scallop (Placopecten magellanicus) larvae. Aquaculture 259, 169-180. https://doi.org/10.1016/j. aquaculture.2006.03.050

Guillard RRL. 1975. Culture of phytoplankton for feeding marine invertebrates. In: Smith WL, Chanley MH (eds.) Culture of marine invertebrate animals. Plenum Press, New York, pp. 26-60.

Hinzpeter I, Shene C, Masson Salaüé L. 2006. Alternativas biotecnológicas para la producción de ácidos grasos poliinsaturados omega-3. Grasas Aceites 57, 336-342.

$\mathrm{Hu} \mathrm{Q}$, Sommerfeld M, Jarvis E, Ghirardi M, Posewitz M, Seibert M, Darzins A. 2008. Microalgal triacylglycerols as feedstock for biofuel production: perspectives and advances. Plant J. 54, 621-639. http://dx.doi. org/10.1111/j.1365-313X.2008.03492.x
Huerlimann R, De Nys R, Heimann K. 2010. Growth, Lipid Content, Productivity, and Fatty Acid Composition of Tropical Microalgae for Scale-Up Production. Biotechnol. Bioeng. 107, 245-257. http://dx.doi. org/10.1002/bit.22809

Knuckey R, Brown M, Barrett S, Hallegraeff G. 2002. Isolation of new nanoplanktonic diatom strains and their evaluation as diets for juvenile Pacific oysters (Crassostrea gigas). Aquaculture 211, 253-274. https://doi.org/10.1016/ S0044-8486(02)00010-8

Levasseur M, Thompson PA, Harrison PJ. 1993. Physiological acclimation of marine phytoplankton to different nitrogen sources. J. Phycol. 29, 587-595 http://dx.doi. org/10.1111/j.0022-3646.1993.00587.x

Medina-Reyna C, Cordero-Esquivel B. 1998. Crecimiento y composición bioquímica de la diatomea Chaetoceros muelleri Lemmerman, mantenida en cultivo estático con un medio comercial. Cienc. Mar 2, 19-25.

Pacheco-Vega JM, Sánchez-Saavedra MP. 2009. The biochemical composition of Chaetoceros muelleri (Lemmermann Grown) with an agricultural fertilizer. J. World Aquacult. Soc. 40, 556-560. http://dx.doi. org/10.1111/j.1749-7345.2009.00276.x

Pierce Chemical Company Manual. Intructions BF3-Methanol; 3747 N. Meridian Road, P.O. Box 117, Rockford, IL 61105, U.S.A.

Prieto M, Mogollon M, Castro A, Sierra L. 2005. Efecto del medio y condiciones de cultivo en la productividad de tres diatomeas marinas con potencial acuícola. MVZ-Córdoba 10, 544-554. ISSN-e1909-0544

Renaud SM, Parry DL, Luong-Van T. 1994. Microalgae for use in tropical aquaculture I: Gross chemical and fatty acid composition of twelve species of microalgae from the Northern Territory, Australia. J. Appl. Phycol. 6, 337-345.

Renaud S, Thinh LV, Lambrinidis G, Parry D. 2002. Effect of temperature on growth, chemical composition and fatty acid composition of tropical Australian microalgae grown in batch cultures. Aquaculture 211, 195-214. https://doi. org/10.1016/S0044-8486(01)00875-4

Rivero-Rodríguez S, Beaumont A, Lora-Vilchis M. 2007. The effect of microalgal diets on growth, biochemical composition and fatty acid profile of Crassostrea corteziensis (Hertlein) juveniles. Aquaculture 263, 199-210. http:// dx.doi.org/10.1016/j.aquaculture.2006.09.038

Rodríguez-Núñez K, Toledo P, Arias S. 2016. Aislamiento de dos especies de diatomeas con potencial acuícolas (Bacillariophyceae) en el Pacífico de Costa Rica. Research Journal of the Costa Rican Distance Education University 8 , 93-98. ISSN:1659-4266.

Roncarati A, Meluzzi A, Acciarri S, Tallarico N, Melotti P. 2004 Fatty acid composition of different microalgae strains (Nannochloropsis sp., Nannochloropsis oculata (Droop) Hibberd, Nannochloris atomus Butcher and Isochrysis sp.) according to the culture phase and the carbon dioxide concentration. J. World Aquacult. Soc. 35, 401-411.

Ryckebosch E, Brunee C, Muylaert K, Foubert I. 2012. Microalgae as an alternative source of omega-3 long chain polyunsaturated fatty acids. Lipid Technol. 24, 128-130. http://dx.doi.org/10.1002/lite.201200197

Simopoulos AP. 2006. Evolutionary aspects of diet, the omega-6/ omega-3 ratio and genetic variation: nutritional implications for chronic diseases. Biomed. Pharmacother. 60, 502-507. http://dx.doi.org/10.1016/j.biopha.2006.07.080

Su X, Xu J, Yan X, Zhao P, Chen J, Zhou C. 2013. Lipidomic changes during differents growth stages of Nizschia closterium f. minutissima. Metabolomics 9, 300-310. http:// dx.doi.org/10.1007/s11306-012-0445-1

Tocher DR. 2015. Omega-3 long-chain polyunsaturated fatty acids and aquaculture in perspective. Aquaculture 449, 94-107. http://dx.doi.org/10.1016/j. aquaculture.2015.01.010

Ward O, Singh A. 2005. Omega $-3 / 6$ fatty acids: alternative sources of production. Process. Biochem. 40, 3627-3652. http://dx.doi.org/10.1016/j.procbio.2005.02.020 